citrate $(23 \%)$. This, together with the improvement in the rate of implantation suggests that prolonged suppression of the pituitary with buserelin may lead to improved quality of oocytes (and therefore of embryos). Further evidence for this is that only eight out of $20(40 \%)$ of women having more than four embryos available after conventional treatment conceived compared with 17 out of 20 $(85 \%)$ treated with buserelin. Alternatively, buserelin may partly produce its effect by direct action on uterine receptivity, but this factor remains to be investigated.

If the success rate reported in this study is maintained it will facilitate the use of in vitro fertilisation for preimplantation diagnosis to treat couples at risk of having a child suffering from genetic disease. An important advantage of treatment with buserelin is that large numbers of fertilisable eggs are produced during one cycle of treatment. This will allow the simultaneous screening of many zygotes for single gene defects for preimplantation diagnosis, such that women at risk could embark on a healthy pregnancy.

\section{References}

1 Voluntary Licensing Authority for Human In Vitro Fertilization and Embryology. Third report. London: Voluntary Licensing Authority, 1988. (Available from the Secretariat, 20 Park Crescent, London W'IN 4AL
2 Wood C, McMaster R, Rennie G, Trounson A, Leeton J. Factors influencing pregnancy rates following in vitro fertilization and embryo transfer. Fertil Steril 1985;43:245-50.

3 Stanger JD, Yovich JL. Reduced in-vitro fertilization of human ocytes from patients with raised basal luteinizing hormone levels during the follicular phase. Br $\mathcal{A}$ Obstet (iynaecol 1985;92: 385-93.

4 Howles CM, MacNamee MC, Edwards RG, Goswamy R, Steptoe PC. Effect of high tonic levels of luteinising hormone on outcome of in-vitro fertilization. Lancet 1986; ; $521-2$.

Salat-Baroux J, Antoine JM, Alvarez S, et al. Programmed induction of ovulation for IVFprogestins or LHRH agonists. Contraception-Fertilite-Sexualite 1987;15:761-3.

6 Lindner C, Braendle W, Lichtenberg V, Bispink L, Bettendorf G. Gonadotrophin-Stimulation und In-vitro-Fertilisation nach selektiver Hypophysen-Suppression durch I.H RH Analogon. und In-vitro-Fcrtilisation nach sclektiver

7 Franks S, Adams J, Mason H, Polson D. Ovulatory disorders in women with polycystic ovary syndrome. Clinics in Obstetrics and (ivneecology 1985;12:605-32

8 Hillier SG, Parsons jH, Margara RA, Winston RML, Crofton ME Serum oestradiol and preovulatory follicular development before in-vitro fertilization. I Endocrinol 1984:101:113-8.
pelatiol and preovulatory follicular development before in-vitro fertilization. I Endocrnol 1984;101:113-8.
McIntosh JEA, Matthews CD, Crocker JM, Broom TJ, Cox LW. Predicting the luteinising hormone surge: relationship between the duration of the follicular and luteal phases and the length of the human menstrual cycle. Feril Steril 1980;30:125-30.

10. Hillier SG, Afnan AMM, Margara RA, Winston RML. Superovulation strategy before in vitro fertilization. Clinics in Obstetrics and Gvnaecology 1985;12:687-723.

11 Fleming R, Coutts JRT. Induction of multiple follicular growth in normally menstruating women with endogenous gonadotrophin suppression. Fertil Steril 1986;45:226-30.

12 Smitz J, Devroey P, Braekmans, el al. Management of failed cycles in an IVF/GIFl programme with the combination of a GnRH analogue and HMG. Hum Reprod 1987;2:309-14.

13 MacNamee MC, Howles CM, Edwards RG. Pregnancies after IVF when high tonic L.H is reduced by long-term treatment with GnRH agonists. Hum Reprod 1987;2:569-71.

14 Fleming R Adam AH, Black WP MacNaughton MC, Couts JRT A new systematic treatment for inferile wom AH, Black WP, MacNaughton MC, Coutts JRT. A new systematic trean

Winston RML. Why a ban on embryo research would be a tragedy. Br Med f 1987;295:1501-2.

\title{
A randomised dose ranging study of recombinant tissue plasminogen activator in acute myocardial infarction
}

\author{
A J MCNEILL, J S SHANNON, S R CUNNINGHAM, D J FLANNERY, N P S CAMPBELL, \\ M M KHAN, G C PATTERSON, S W WEBB, A A J ADGEY
}

\begin{abstract}
To assess the thrombolytic efficacy and the effect on the systemic fibrinolytic system of recombinant tissue plasminogen activator doses of $20 \mathrm{mg}, 50 \mathrm{mg}$, and $100 \mathrm{mg}$ were compared in a randomised study. Tissue plasminogen activator was infused intravenously over $\mathbf{9 0}$ minutes in $\mathbf{5 0}$ consecutive patients with acute myocardial infarction of four hours' duration or less; on average the infusion was started 135 minutes (range 20 to 240) after the onset of pain. The affected artery was patent at the end of the 90 minute infusion in $14 / 17(82 \%)$ of those who received $100 \mathrm{mg}, 12 / 17(71 \%)$ of those who received $50 \mathrm{mg}$, and $8 / 16(50 \%)$ of those who received $20 \mathrm{mg}$. Regardless of dose, reperfusion rates were significantly better for patients treated within two hours of the onset of symptoms $(81 \%)$ than for those treated in the third and fourth hours $(54 \%)$. At the end of the infusion serum fibrinogen concentrations fell to $86 \%$ of the preinfusion value after $20 \mathrm{mg}, 75 \%$ after $50 \mathrm{mg}$, and $63 \%$ after $100 \mathrm{mg}$, and similar dose dependent changes occurred in plasminogen, $\alpha_{2}$ anti-
\end{abstract}

\footnotetext{
Regional Medical Cardiology Centre, Royal Victoria Hospital, Belfast BT12 6BA

A J MCNEILL, MB, MRCP, research fellow

I S SHANNON, MD, MRCP, registrar

S R CUNNINGHAM, MD, MRCP, research fellow

D J FLANNERY, MB, MRCP, research fellow

N P S CAMPBELL, MD, MRCP, consultant cardiologist

M M KHAN, $\mathrm{MB}, \mathrm{MRCP}$, consultant cardiologist

G C PATTERSON, MD, PHD, consultant cardiologist

S W WEBB, MD, MRCP, consultant cardiologist

A A J ADGEY, MD, FRCP, consultant cardiologist

Correspondence to: Dr Adgey.
}

plasmin, and fibrinogen and fibrin degradation products. The mean infarct related regional third ejection fraction was $46 \%$ for patients with grade 2 or 3 reperfusion and 35\% for those with grade 0 or 1 . Ventricular fibrillation occurred in six $(12 \%)$ patients during the infusion of tissue plasminogen activator, but no late ventricular fibrillation occurred. Bleeding was minimal, reocclusion occurred in three patients, and four patients died from cardiac causes.

Recombinant tissue plasminogen activator is an effective thrombolytic agent which produces better reperfusion rates after a 50 or $100 \mathrm{mg}$ dose than after a $20 \mathrm{mg}$ dose. The effect on the systemic fibrinolytic system is dose dependent. Successful reperfusion results in improvement of left ventricular function.

\section{Introduction}

Although streptokinase has been used as a thrombolytic agent for at least 30 years, ' its use when administered directly into a coronary artery has become feasible only with the emergence of coronary angiography as a safe procedure in acute myocardial infarction. Intravenous administration of streptokinase allows earlier, safer, and more practicable treatment than intracoronary administration.

Nevertheless, streptokinase has several potential disadvantages. It causes thrombolysis by activating plasminogen to plasmin, which in turn breaks down fibrin to fibrin degradation products. Streptokinase causes a generalised fibrinolytic state by activating plasmin in the circulation as well as at the fibrin surface of the clot. Its antigenic potential results in antibody formation with a risk of anaphylaxis and an anamnestic response on subsequent exposure, possibly during reocclusion, and the long half life makes emergency surgical intervention difficult. These disadvantages have led to the search for 
thrombolytic agents which are clot specific, have no antigenic potential, and have a short half life. 'Tissue plasminogen activator is the physiological thrombolytic agent with relative clot specificity produced by endothelial cells. Therapeutic quantities are now available, produced initially from melanoma cells ${ }^{3}$ and now by recombinant DNA technology. ${ }^{+}$

Recombinant tissue plasminogen activator is an effective thrombolytic agent in acute myocardial infarction, producing reperfusion in the affected artery in $61-62 \%$ of patients at 90 minutes compared with reperfusion in $31 \%$ of patients after intravenous streptokinase."

A randomised dose ranging study with recombinant tissue plasminogen activator has not, however, been carried out. We therefore assessed the thrombolytic efficacy and the effect on the systemic fibrinolytic system of different doses of tissue plasminogen activator administered intravenously to patients with acute myocardial infarction.

\section{Patients and methods}

Study population-Consecutive patients with pain who were suspected clinically of having suffered an acute myocardial infarction were considered for entry into the study. Patients were admitted via the mobile coronary care unit, from the accident and emergency department, and from other hospital wards.

Entry criteria-Patients were entered into the study if they were aged under 75 years and had ST segment elevation of at least $0.2 \mathrm{mV}$ in the electrocardiogram in at least two inferior leads, of $0.3 \mathrm{mV}$ in at least two precordial leads, or of $0.2 \mathrm{mV}$ in leads I and aVL. The time limit between the onset of pain and the start of treatment was up to four hours.

Exclusion criteria-Patients were excluded if they were of childbearing potential; were in cardiogenic shock; had a history of bleeding diathesis or using anticoagulant drugs; had undergone cardiac surgery, recent surgery, or trauma; had severe hypertension or any general medical condition precluding thrombolytic treatment, had had a stroke, or had an electrocardiogram showing left bundle branch block.

Trial design-Patients were randomised to receive $20 \mathrm{mg}, 50 \mathrm{mg}$, or $100 \mathrm{mg}$ recombinant tissue plasminogen activator infused intravenously over 90 minutes. The randomisation was prepared from a random number sequence, and the drug was supplied in numbered packs, which were used in sequence. Reperfusion was assessed by coronary angiography performed at the end of the 90 minute infusion. Although the investigator who performed the coronary arteriography was aware of the dose of tissue plasminogen activator, the angiograms were subsequently viewed and graded by two investigators who were blind to the dose given.

Treatment and administration-The randomised dose of recombinant tissue plasminogen activator (double chain), which was provided by Wellcome Research Laboratories, was supplied as a white lyophilised powder which was dissolved in sterile water and infused intravenously over 90 minutes using a battery powered infusion pump (Graseby MS 2000). Treatment was started in the coronary care unit, accident and emergency department, or ward or outside hospital by mobile coronary care unit staff.

Trial observations-Before tissue plasminogen activator was started the patient's age, sex, medical history, and physical findings were documented and a standard 12 lead electrocardiogram recorded. Blood was drawn for measuring cardiac enzyme activities (total creatine kinase and creatine kinase $M B$ isoenzyme) and clotting factors-serum fibrinogen, plasminogen, $\iota_{2}$ antiplasmin, and fibrin and fibrinugen degradation products. Coronary arteriography by the Judkins technique was performed at the end of the 90 minute infusion, and the reperfusion grade of the affected coronary artery assessed and scored using thrombolysis in myocardial infarction (TIMI) grades 0-3 (grade 0 no perfusion, grade 1 penetration with minimal perfusion, grade 2 partial perfusion, grade 3 complete perfusion). Angiograms were subsequently viewed and scored by two investigators blinded to the dose given. Clotting factors were assayed from blood taken at the end of the 90 minute infusion and four hours and 24 hours after the start of treatment. Blood was drawn into citrate tubes (Sarstedt Monovette) and immediately placed in ice and centrifuged within 30 minutes at $600-1000 \mathrm{~g}$ for 10 to 15 minutes. Plasma was then transferred in $500 \mu$ aliquots to tubes containing antibody to tissue plasminogen activator, thereby preventing continuing in vitro fibrinogenolysis. Tubes were frozen immediately to $-20^{\circ} \mathrm{C}$ and transported in dry ice for analysis. Specimens were analysed for fibrinogen (Clauss method), plasminogen (streptokinase assay), $\alpha_{2}$ antiplasmin (functional assay), and fibrin and fibrinogen degradation products (enzyme immunoassays). Cardiac enzyme activities were measured on specimens drawn every four hours after the start cf treatment for 28 hours. Total creatine kinase was assayed by an optimised standard method
(Randox Laboratories Ltd) using a parallel analyser (American Monitor). Creatine kinase $M B$ was assayed by an immunoassay method adapted for the Roche Cobos Bio Centrifugal Analyser (Boehringer Mannheim GmbH Diagnostica).

Subsequent management-Management after the 90 minute angiogram was decided on by the senior investigator who performed catheterisation, with the aim of improving patency in a vessel with grade 0 or 1 reperfusion or maintaining patency in a vessel with grade 2 or 3 reperfusion. When possible patients underwent assessment of left ventricular function by gated blood pool scanning during their stay in hospital.

Statistical methods-Univariate methods of statistical analysis were used. Clotting factors were analysed using one way analysis of variance. Reperfusion grades for the different doses were examined using the $\chi^{2}$ test for association. Cardiac enzyme activities and regional and global ejection fractions were analysed with unpaired $t$ tests. The conventional $5 \%$ level of statistical significance was adopted as standard.

\section{Results}

Study population-Fifty consecutive patients (41 men and nine women) with a mean age of 59 (range 42-71) were studied. Twenty three had anterior infarction and 27 inferior infarction. Treatment was started at a mean of 135 minutes after the onset of pain (range 20-240 minutes). In 20 patients treatment was started outside hospital by the mobile coronary care unit staff.

Reperfusion rates-Coronary artery patency (conventionally taken as TIMI grade 2 or 3 ) was seen in 14 out of 17 patients $(82 \%)$ who received $100 \mathrm{mg}$, in 12 out of $17(71 \%)$ who received $50 \mathrm{mg}$, and in eight out of 16 $(50 \%)$ who received $20 \mathrm{mg}\left(\chi^{2}=4.04, \mathrm{p}>0.05\right)$ (table I). There was no statistical difference in patency rates after the $50 \mathrm{mg}$ and $100 \mathrm{mg}$ doses (difference in proportions $=11 \cdot 8 \%, \mathrm{SE}=14 \cdot 5 \%, 95 \%$ confidence interval $-17 \cdot 2 \%$ to $40 \cdot 8 \%$ ). The overall reperfusion rate (grades 2 and 3 ) for patients treated up to 120 minutes after the onset of pain was $81 \%$ regardless of dose $(10 / 10$ receiving $100 \mathrm{mg}, 5 / 5$ receiving $50 \mathrm{mg}$, and $6 / 11$ receiving $20 \mathrm{mg}$ ) and was significantly better than for those treated between 121 and 240 minutes-that is, $54 \%(4 / 7$ receiving $100 \mathrm{mg}, 7 / 12$ receiving $50 \mathrm{mg}$, and $2 / 5$ receiving $20 \mathrm{mg})\left(\chi^{2}=4.058, \mathrm{p}<0.05\right)($ table II).

TABLE I-Reperfusion grades in the affected artery after tissue plasminogen activator according to dose

\begin{tabular}{lcccc}
\hline & \multicolumn{3}{c}{ Dose of tissue plasminogen activator } & \\
\cline { 2 - 5 } $\begin{array}{l}\text { Reperfusion } \\
\text { grade }\end{array}$ & $20 \mathrm{mg}$ & $50 \mathrm{mg}$ & $100 \mathrm{mg}$ & Total \\
\hline 0 & 4 & 4 & 1 & 9 \\
1 & 4 & 1 & 2 & 7 \\
2 & 3 & 5 & 4 & 12 \\
3 & 5 & 7 & 10 & 22 \\
\hline Total & 16 & 17 & 17 & 50 \\
\hline$\%^{2}=6 \cdot 22 ; \mathrm{df}=6, \mathrm{p}>0 \cdot 05$ & & &
\end{tabular}

TABLE II-Patency rate in affected coronary artery by time from onset of symptoms to start of tissue plasminogen activator infusion

\begin{tabular}{|c|c|c|c|}
\hline \multirow{2}{*}{$\begin{array}{l}\text { Time } \\
(\min )\end{array}$} & \multicolumn{2}{|c|}{$\begin{array}{l}\text { Patients with reperfusion } \\
\text { grades }\end{array}$} & \multirow{2}{*}{$\begin{array}{c}\text { Patency } \\
\text { rate } \\
\%\end{array}$} \\
\hline & 0 and 1 & 2 and 3 & \\
\hline $\begin{array}{c}0-60 \\
61-120\end{array}$ & $\begin{array}{l}0 \\
5\end{array}$ & $\begin{array}{r}5 \\
16\end{array}$ & $\left.{ }_{76}^{100}\right\}^{81^{*}}$ \\
\hline $\begin{array}{l}121-180 \\
181-240 \\
\end{array}$ & $\begin{array}{l}6 \\
5 \\
\end{array}$ & $\begin{array}{l}6 \\
7 \\
\end{array}$ & $\begin{array}{l}501 \\
58\}^{54}\end{array}$ \\
\hline Total & 16 & 34 & \\
\hline
\end{tabular}

Clotting factors-The reduction in serum fibrinogen concentration was dose related (figure, table III). It fell to a mean of $86.3 \%$ (SD 14.9) after $20 \mathrm{mg}$, to $75 \cdot 1(14 \cdot 1)$ after $50 \mathrm{mg}$, and to $62 \cdot 8(20 \cdot 6)$ after $100 \mathrm{mg}$ when assessed at 90 minutes after the start of infusion $(p=0.001)$. There were similar dose dependent changes in plasminogen, $\alpha_{2}$ antiplasmin, and total fibrinogen and fibrin degradation products (table III).

Subsequent management-After the initial infusion 41 patients received a further $50 \mathrm{mg}$ tissue plasminogen activator over the next five hours followed 
by intravenous heparin in an effort to maintain patency of the affected vessel. To improve patency in a vessel with grade 0 or 1 reperfusion seven patients received $50 \mathrm{mg}$ tissue plasminogen activator over one hour followed by intravenous heparin. Three patients underwent mechanical probing of the affected artery, and eight received nitrates infused directly into the narrowed coronary artery. Ten patients underwent acute percutaneous transluminal coronary angioplasty because of residual stenosis of $85 \%$ or more in the affected vessel, and a further two underwent elective percutaneous transluminal coronary angioplasty during their stay in hospital. Twelve patients required coronary artery bypass grafting (10 of whom had severe three vessel disease), one as an emergency because of the severity of his coronary artery disease.

Cardiac enzyme activities-All patients had abnormal cardiac enzyme values. Patients undergoing direct current conversion or further acute revascularisation procedures were excluded from enzyme analysis. There was no difference in mean peak creatine kinase or creatine kinase MB values between patients with grade 0 or 1 reperfusion (total creatine kinase 2541 (SEM 278) U/l and MB isoenzyme 290 (32) U/l) and those with grade 2 or 3 reperfusion $(2187$ (405) $\mathrm{U} / \mathrm{l}$ and $212(39) \mathrm{U} / \mathrm{l})$.

Left ventricular function-Gated blood pool scans were carried out a mean of 46 hours after the onset of pain. Global and infarct related regional third ejection fractions were calculated using the left anterior oblique $45^{\circ}$ view. Patients undergoing other acute reperfusion treatment-acute percutaneous transluminal coronary angioplasty, coronary artery probing, intracoronary nitrates, or coronary artery grafting-were excluded from the analysis of ejection fraction. There was no difference in mean global left ventricular ejection fraction between patients with grade 2 or 3 reperfusion $(48 \%$ SEM $3 \cdot 7)$ ) and those with grade 0 or 1 reperfusion $(41 \%(3 \cdot 7)$ ) (table IV). Infarct related regional third ejection fraction for patients with grade 2

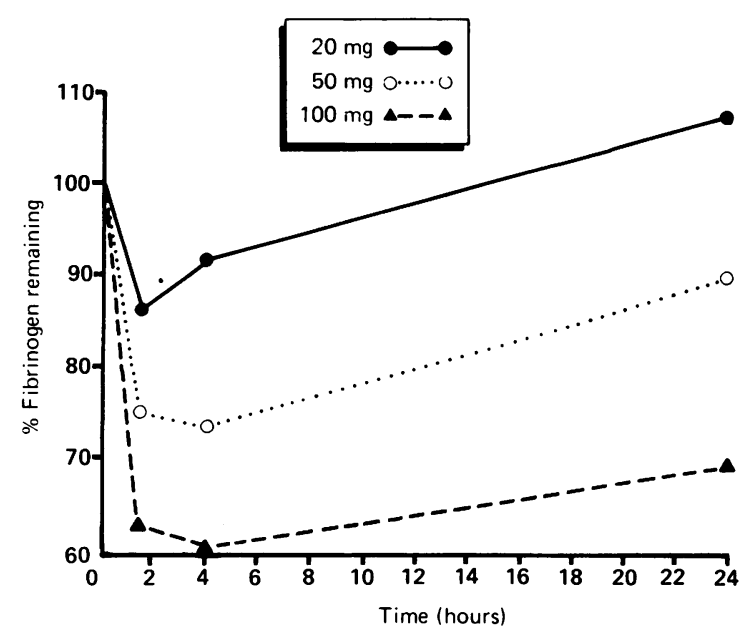

Percentage fibrinogen remaining after 20,50 , and $100 \mathrm{mg}$ doses of tissue plasminogen activator.

TABLE III-Twenty four hour clotting factor profiles for the three doses of tissue plasminogen activator. Results are means (SD)

\begin{tabular}{|c|c|c|c|c|c|}
\hline & \multirow{2}{*}{$\underset{(\mathrm{h})}{\text { Time }}$} & \multicolumn{3}{|c|}{ Dose over 90 minutes } & \multirow[b]{2}{*}{ p Value } \\
\hline & & $20 \mathrm{mg}$ & $50 \mathrm{mg}$ & $100 \mathrm{mg}$ & \\
\hline \multirow{3}{*}{$\begin{array}{l}\% \text { Fibrinogen } \\
\text { remaining }\end{array}$} & 1.5 & $86 \cdot 3(14 \cdot 92)$ & $75 \cdot 1(14 \cdot 12)$ & $62 \cdot 8(20 \cdot 61)$ & \multirow[t]{3}{*}{0.001} \\
\hline & 4 & $91.8(15 \cdot 30)$ & $73.6(18.70)$ & $60.4(18.05)$ & \\
\hline & 24 & $107 \cdot 6(23 \cdot 10)$ & $90 \cdot 3(27 \cdot 59)$ & $69 \cdot 9(21 \cdot 37)$ & \\
\hline \multirow{3}{*}{$\begin{array}{l}\% \text { Plasminogen } \\
\text { remaining }\end{array}$} & 1.5 & $85.4(6.85)$ & $73 \cdot 3(13.35)$ & $72 \cdot 4(6 \cdot 92)$ & \multirow{3}{*}{0.001} \\
\hline & 4 & $83.4(8.37)$ & $75.0(13.80)$ & $73 \cdot 1(6 \cdot 12)$ & \\
\hline & 24 & $87 \cdot 8(11 \cdot 53)$ & $75 \cdot 1(12 \cdot 46)$ & $74.9(13.42)$ & \\
\hline \multirow{3}{*}{$\begin{array}{l}\text { or, Antiplasmin } \\
\text { remaining }\end{array}$} & 1.5 & $65 \cdot 1(10 \cdot 13)$ & $36.9(15 \cdot 86)$ & $24.5(11.28)$ & \multirow[t]{3}{*}{0.0001} \\
\hline & 4 & $50.8(17.51)$ & $30.9(19.99)$ & $22 \cdot 4(15 \cdot 47)$ & \\
\hline & 24 & $72 \cdot 5(12.48)$ & $57.5(13.50)$ & $54 \cdot 2(13 \cdot 14)$ & \\
\hline \multirow{4}{*}{$\begin{array}{l}\text { Total degradation } \\
\text { products }(\mathrm{mg} / \mathrm{l})\end{array}$} & 0 & $0.71(0.21)$ & $0.86(0.48)$ & $0.69(0.43)$ & \multirow{4}{*}{0.046} \\
\hline & 1.5 & $1.90(1.08)$ & $5.45(4.55)$ & $8.32(11.35)$ & \\
\hline & 4 & $2.77(1.67)$ & $7.41(4.99)$ & $6.81(4.99)$ & \\
\hline & 24 & $1.51(1.52)$ & $1.86(1.81)$ & $2.48(3.69)$ & \\
\hline \multirow{4}{*}{$\begin{array}{l}\text { Fibrinogen } \\
\text { degradation } \\
\text { products }(\mathrm{mg} /)\end{array}$} & 0 & $0.55(0.13)$ & $0.56(0.11)$ & $0.55(0.14)$ & \multirow{4}{*}{0.05} \\
\hline & 1.5 & $0.81(0.41)$ & $1.93(1.31)$ & $2 \cdot 51(3 \cdot 10)$ & \\
\hline & 4 & $1 \cdot 13(0.49)$ & $2 \cdot 23(1 \cdot 25)$ & $2.81(2.60)$ & \\
\hline & 24 & $0.81(0.62)$ & $0.85(0.73)$ & $1.13(1.15)$ & \\
\hline \multirow{4}{*}{$\begin{array}{c}\text { Fibrin degradation } \\
\text { products }(\mathbf{m g} / \mathbf{l})\end{array}$} & 0 & $0.51(0.03)$ & $0.59(0.24)$ & $0.53(0.12)$ & \multirow{4}{*}{0.07} \\
\hline & 1.5 & $1.15(0.85)$ & $3 \cdot 49(3 \cdot 20)$ & $5.48(8.40)$ & \\
\hline & 4 & $1.93(1.47)$ & $5.01(3.71)$ & $3.96(3.18)$ & \\
\hline & 24 & $0.87(0.73)$ & $1.02(0.74)$ & $1.43(2.04)$ & \\
\hline
\end{tabular}

TABLE IV-Mean global left ventricular ejection fraction and infarct related regional third ejection fraction for patients with grade 2 or 3 reperfusion compared with those with grade 0 or $1^{\star}$

\begin{tabular}{lcc}
\hline & \multicolumn{2}{c}{ Reperfusion grade } \\
\cline { 2 - 3 } & $\begin{array}{c}2 \text { or } 3 \\
(\mathrm{n}=20)\end{array}$ & $\begin{array}{c}0 \text { or } 1 \\
(\mathrm{n}=8)\end{array}$ \\
\hline No with affected artery: & & \\
$\quad$ Left anterior descending coronary artery & 7 & 5 \\
Right coronary artery & 10 & 2 \\
Circumflex coronary artery & 3 & 1 \\
Mean global left ventricular ejection fraction $(\%)$ & 48 & 41 \\
Mean regional third ejection fraction (\%) & 46 & 35 \\
\hline
\end{tabular}

*Patients undergoing additional acute reperfusion treatment resulting in change in patency from grade at 90 minutes were excluded.

or 3 reperfusion was $46(3 \cdot 6 \%)$ compared with $35(4 \cdot 7 \%)$ for patients with grade 0 or 1 reperfusion $(0.05<p<0 \cdot 1)$. This statistical result was based on the assumption that reperfusion may result in either improvement or deterioration of regional ejection fraction. Assuming, as is likely, that regional ejection fraction can only improve after reperfusion then the observed difference can be declared to be statistically significant on the basis of a one tailed $t$ test $(\mathrm{p}<0.05)$.

Arrhythmias-At the start of recombinant tissue plasminogen activator treatment all patients were in sinus rhythm, although three had had third degree atrioventricular block when first seen. Twenty patients had one or more arrhythmias during the 90 minute infusion. Four patients developed ventricular fibrillation during the infusion (one during cardiac catheterisation): three of the four had grade 1 and one had grade 2 reperfusion. Two patients had idioventricular rhythm, two had self terminating ventricular tachycardia (five or more consecutive ventricular extrasystoles), six had runs of ventricular bigeminy, two had atrial fibrillation (self terminating), one had transient 2:1 atrioventricular block, three had nodal rhythm (two nodal bradycardia, one nodal tachycardia), and two had sinus bradycardia. Among the seven patients who received $50 \mathrm{mg}$ tissue plasminogen activator for a further hour after the initial infusion one patient developed idioventricular rhythm and nodal rhythm during the extra hour. Among the 41 patients who received $50 \mathrm{mg}$ for a further five hours two patients developed ventricular fibrillation (one grade 2 and one grade 3 reperfusion), nine had idioventricular rhythm, and six had self terminating ventricular tachycardia during this extra period. There was no late persistent ventricular tachycardia or late ventricular fibrillation during the stay in hospital.

Complications in hospital-Four patients developed pericarditis during their stay in hospital. One had grade 3, one grade 2, and one who also had exacerbation of renal failure, had grade 1; the fourth patient had grade 2 reperfusion at 90 minutes but suffered reocclusion and then developed pericarditis. Ten patients had clinical or radiological evidence (or both) of left ventricular failure after tissue plasminogen activator during their stay in hospital: the worst Killip class after tissue plasminogen activator was class 1 in one patient, class 2 in five, and class 4 in four. Throughout their stay in hospital bleeding complications were mild. One patient with unsuspected polycystic renal disease bled into a renal cyst while receiving heparin and required transfusion with one unit of packed cells. One patient with gross pulmonary oedema had haemoptysis, one had bloody diarrhoea, and 15 had cutaneous bruising at the catheterisation or venepuncture sites, or both. Reocclusion was suspected clinically in five patients. All five underwent repeat angiography, which confirmed reocclusion in three. Four patients died, all from cardiac causes: three from cardiogenic shock and one from renal failure complicating cardiogenic shock. Two of these four had had an anterior myocardial infarction and two an inferior myocardial infarction, and three of the four had severe disease with either total occlusion or high grade lesions in both the circumflex and left anterior descending coronary arteries. Two patients had had grade 0 reperfusion at 90 minutes, one grade 2 , and one grade 3: the last patient had angiographically proved reocclusion two days after tissue plasminogen activator. Three of the four patients came to necropsy and all had extensive myocardial damage.

\section{Discussion}

The primary end points of this dose ranging study were the reperfusion grade of the affected coronary artery and the change in the fibrinolytic system at the end of the 90 minute infusion.

Reperfusion rates were higher after the two larger doses- $100 \mathrm{mg}$ and $50 \mathrm{mg}$. Although the reperfusion rates after these doses were not significantly different from those after the $20 \mathrm{mg}$ dose, the 
difference was clinically important enough for us to discontinue use of the $20 \mathrm{mg}$ dose. For patients receiving $100 \mathrm{mg}$ the patency rate (grade 2 or 3 ) was $82 \%$. This compares favourably with reported reperfusion grades of $61-62 \%{ }^{56}$ for tissue plasminogen activator and $31 \%$ for streptokinase ${ }^{6}$ when patients had coronary arteriography 90 minutes after the start of the infusion. For patients treated within two hours of the onset of symptoms the overall reperfusion rate (grade 2 or 3 ) was $81 \%$ regardless of dose compared with $54 \%$ for those treated in the third and fourth hours after the onset of symptoms.

These results support the view that thrombolytic treatment should be started as soon as possible after the onset of symptoms. ${ }^{\text {? }}$ The absence of data on the pretreatment grade of the affected artery may have resulted in our reperfusion rates being falsely high, but acquiring such baseline data would have delayed the start of treatment. As all patients in this dose ranging study had abnormal cardiac enzyme activities, the incidence of subtotal occlusion must have been low.

Blood clotting factor measurements showed that the upset in the fibrinolytic system was dose dependent. The reduction in serum fibrinogen values and rise in fibrinogen derived degradation products indicate the relative but not absolute clot specificity of tissue plasminogen activator. Nevertheless, the maximum reduction in fibrinogen concentration seen after the $100 \mathrm{mg}$ infusion (to $63 \%$ ) compared favourably with a fall to $7 \%$ of the preinfusion values after streptokinase. ${ }^{8}$

Even with the upset in fibrinolysis after the $100 \mathrm{mg}$ infusion over 90 minutes, the incidence of bleeding in hospital was low and confined mainly to vascular access sites. Scrupulous care with these sites after catheterisation and venepuncture and retention of the catheterisation sheath while thrombolytic treatment is being continued produce a low incidence of cutaneous bruising. We also think that the low incidence of haemorrhagic complications was related to the strict application of the exclusion criteria. The one patient who required transfusion had polycystic renal disease, which would have precluded thrombolytic treatment had we known of it before starting treatment.

The lower creatine kinase and creatine kinase MB isoenzyme values in patients with successful reperfusion suggest limitation of myocardial damage with successful reperfusion. The accuracy of this assumption is, however, limited by the change in enzyme profile which occurs after successful reperfusion ${ }^{9}$ and by the absence of complete enzyme data in two of the four patients who died. In this study, where gated blood pool scans were carried out on average 46 hours after the onset of pain, there was no significant difference in global left ventricular ejection fraction between those with grade 2 or 3 reperfusion $(48 \%)$ and those with grade 0 or 1 reperfusion $(41 \%)$. The infarct related regional third ejection fraction for patients with grade 2 or 3 reperfusion was $46 \%$ compared with $35 \%$ for those with grade 0 or 1 reperfusion, and this difference was statistically significant on the basis of a one tailed $t$ test. There were more right coronary artery and circumflex lesions among those with grade 2 or 3 reperfusion than among those with grade 0 or 1 reperfusion, but comparisons are difficult because of the small numbers of patients with grade 0 or 1 reperfusion.

The reocclusion rate of $6 \%$ in hospital is low and compares favourably with figures of up to $45 \%$ quoted in other studies of intravenous tissue plasminogen activator. ${ }^{10}$ The short half life of tissue plasminogen activator increases the theoretical risk of reocclusion. The low incidence of reocclusion we reported may have been due to the use of a low dose infusion over five hours after the initial infusion in most of our patients, the rationale for which is based on studies in dogs ${ }^{11}$ and in humans. ${ }^{10}$

Reports on the benefit of percutaneous transluminal angioplasty immediately after thrombolysis are conflicting. ${ }^{12}{ }^{13}$ Angioplasty was considered to be feasible and necessary in the acute phase in only 10 of these 50 patients, in all of whom either the lesions in their arteries were thought to be at high risk of reocclusion or thrombolytic treatment had failed. The procedure was successful in five (reduction in gradient or improvement in angiographic appearances, or both). The commonest reason for failure of the procedure was inability to cross the residual lesion. Angioplasty in patients with residual thrombus partially occluding the lumen was associated with a high incidence of complications; two of these patients underwent reocclusion at the time of angioplasty and a further patient reoccluded two days after the procedure. Our results suggest that acute percutaneous transluminal coronary angioplasty in patients with residual thrombus is of limited value. In contrast, both patients who underwent elective angioplasty did so successfully. Thus seven patients underwent successful angioplasty, and this may be an additional factor in our low reocclusion rate.

Six patients developed ventricular fibrillation during either the initial infusion or the subsequent low dose infusion. This incidence is no higher than that occurring in patients seen in the same time period who do not receive thrombolytic treatment. This suggests that reperfusion is gradual rather than sudden. Only four patients developed pericarditis, and no patients developed late sustained ventricular tachycardia or late ventricular fibrillation. This suggests that reperfusion limits the infarct size and therefore the potential for late arrhythmias. All four patients who died had extensive myocardial damage and all died from cardiac causes. No death was attributable to thrombolytic therapy.

Recombinant tissue plasminogen activator is an effective thrombolytic agent when used early in patients with acute myocardial infarction. Reperfusion grades are better when the 50 and $100 \mathrm{mg}$ doses are infused intravenously over 90 minutes, but beginning treatment early allows high reperfusion rates, even when using the $20 \mathrm{mg}$ dose. The effect on the systemic fibrinolytic system is mild and dose dependent but even with the highest doses used bleeding complications are minimal provided scrupulous care is taken with vascular access sites and patients are carefully screened for potential bleeding diatheses. There is improvement in the left ventricular global ejection fraction, particularly in the infarct related regional third ejection fraction, for those with grade 2 or 3 reperfusion when compared with those with grade 0 or 1 reperfusion. The incidence of arrhythmias after treatment is similar to that in patients with acute myocardial infarction who do not receive thrombolytic therapy.

We thank the medical, nursing, and technical staff of our unit, without whose cooperation this study would have been impossible; the staff of the Wellcome Research Laboratories for supplying recombinant tissue plasminogen activator; Dr Kluft, Gaubius Institute, Leiden, for performing clotting factor analysis; and Dr Gilbert MacKenzie, Department of Community Medicine, Queen's University, Belfast, for statistical advice. AJMcN, SRC, and DJF are Royal Victoria Hospital research fellows.

\section{References}

1 Fletcher AP, Sherry S, Alkjaersig N, Smyrniotis FE, Jick S. The maintenance of a sustained thrombolytic state in man. II. Clinical observations on patients with myocardial infarction and thrombolytic state in man. II. Clinical observations on patients

2 Collen D, Verstraete $M$. Systemic thrombolytic therapy of acute myocardial infarction? Circulation 1983;68:462-5.

3 Collen D. Human tissue-type plasminogen activator from the laboratory to the bedside. Circulation 1985;72:18-20.

4 Pennica D, Holmes WE, Kohr WJ, et al. Cloning and expression of human tissue-type plasminogen activator CDNA in E coli. Nature 1983;301:214-21.

5 Verstraete $M$, Brower RW, Collen D, et al. Double-blind randomised trial of intravenous tissuetype plasminogen activator versus placebo in acute myocardial infarction. Lancet 1985;ii:965-9.

6 Chesebro JH, Knatterud G, Roberts R, et al. Thrombolysis in myocardial infarction (TIMI) trial, phase 1: a comparison between intravenous tissue plasminogen activator and intravenous streptokinase. Circulation 1987;76:142-54.

streptokinase. Circulation 1987;76:142-54.
7 Simoons ML, Lubsen J, Serruys PW, Hugenholiz PG. Thrombolytic therapy for acute coronary thrombosis. Eur Heart f 1987;8(suppl F):78-87.

8 Collen D, Bounameaux H, De Cock F, Lijnen HR, Verstraete M. Analysis of coagulation and Collen D, Bounameaux $\mathrm{H}$, De Cock F, Lijnen HR, Verstraete $\mathrm{M}$. Analysis of coagulation and
fibrinolysis during intravenous infusion of recombinant human tissue-type plasminogen fibrinolysis during intravenous infusion of recombinant human tissue-type

9 Blanke $\mathrm{H}$, von Hardenberg $\mathrm{D}$, Cohen $\mathrm{M}$, et al. Patterns of creatine kinase release during acute myocardial infarction after non-surgical reperfusion: comparison with conventional treatment and correlation with infarct size. Foumal of the American College of Cardiology 1984;3:675-80.

10 Gold HK, Leinbach RC, Garabedian HD, et al. Acute coronary reocclusion after thrombolysis with recombinant human tissue-type plasminogen activator: prevention by a maintenance infusion. Circulation 1986;73:347-52.

11 Fox KAA, Robison AK, Knabb RM, Rosamond TL, Sobel BE, Bergmann SR. Prevention of coronary thrombosis with subthrombolytic doses of tissue-type plasminogen activator. Circulation 1985;72:1346-54.

12 Topol EJ, O'Neill WW, Langburd AB, et al. A randomized placebo controlled trial of intravenous recombinant tissue-type plasminogen activator and emergency coronary angioplasty in patients with acute myocardial infarction. Circulation 1987;75:420-8

13 Topol EJ, Califf RM, George BS, et al. A randomized trial of immediate versus delayed elective angioplasty after intravenous tissue plasminogen activator in acute myocardial infarction. N Engl f Med 1987;317:581-8. 